\title{
Longitudinal study of aspergillosis in sea fan corals
}

\author{
Kiho Kim $^{1, *}$, Alisa P. Alker ${ }^{2,5}$, Kara Shuster ${ }^{1,4}$, Craig Quirolo ${ }^{3}$, C. Drew Harvell ${ }^{2}$ \\ ${ }^{1}$ Department of Biology, American University, 4400 Massachusetts Ave., NW, Washington, DC 20016, USA \\ ${ }^{2}$ Ecology \& Evolutionary Biology, Cornell University, Ithaca, New York 14853, USA \\ ${ }^{3}$ Reef Relief, Historic Seaport, 201 Williams St., \#5, Key West, Florida 33040, USA \\ ${ }^{4}$ Donald Bren School of Environmental Science \& Management, University of California, Santa Barbara, Santa Barbara, \\ California 93106-5131, USA \\ ${ }^{5}$ Present address: Department of Epidemiology, CB\#7435, University of North Carolina, Chapel Hill, \\ North Carolina 27599, USA
}

\begin{abstract}
Aspergillosis (a fungal disease) is affecting sea fan corals Gorgonia spp. throughout the Caribbean. To measure the impact of this disease, we established longitudinal, or in other words individual-based, monitoring studies on 3 reefs in the Florida Keys, USA, to obtain estimates of incidence, rates of disease progress, recovery, and mortality. At Western Dry Rocks (near Key West), 40 Gorgonia ventalina colonies (20 initially healthy and 20 initially diseased) were photomonitored between June 1996 and May 1998. Additional sea fans were visually monitored during 2 localized outbreaks at Conch (May 1998 to September 1999) and Carysfort (July 2000 to May 2001) reefs located in the Upper Keys. Data from Western Dry Rocks showed that over a 2 yr period, the incidence rate was 0.58 sea fans $\mathrm{yr}^{-1}$ and that tissue purpling can lead to tissue loss and subsequently to mortality, albeit at low frequencies. Most sea fans, once infected, maintained a low level of damage over time. Only 3 fans recovered from the disease; however 2 were subsequently re-infected. Case fatality rate was $10 \%$ (2 of 20 initially infected died), which is equivalent to $5 \%$ $\mathrm{yr}^{-1}$. However, mortality can increase during localized outbreaks. At Conch, mortality was $46 \%$ $\mathrm{yr}^{-1}$ among infected sea fans (compared to $8 \% \mathrm{yr}^{-1}$ at Carysfort, a less impacted site, during the same period). During an outbreak at Carysfort, mortality was $95 \% \mathrm{yr}^{-1}$ among diseased sea fans. These data clearly demonstrate the significant role aspergillosis plays in the population ecology of sea fan corals.
\end{abstract}

KEY WORDS: Gorgonia ventalina $\cdot$ Aspergillus sydowii $\cdot$ Coral disease $\cdot$ Host-pathogen interaction

\section{INTRODUCTION}

Recent increases in diseases of marine organisms have highlighted the need for establishing long-term monitoring of disease dynamics (Harvell et al. 1999, Ward \& Lafferty 2004). Data from such studies are critical for fully assessing impact on host populations (Kim \& Harvell 2004) as well for addressing fundamental questions of whether disease dynamics in marine systems, and thus, methods for their control, are different than those on land (McCallum et al. 2004). For instance, the ubiquity of modular forms (e.g. sponges, corals, hydrozoans, bryozoans) in marine benthic environments can result in reduced genetic variability (among clonal species) or increased host size (among colonial species), and thus enhance the probability of acquiring, accumulating, and spreading disease (McCallum et al. 2004).

In the marine realm, coral reefs are among the most threatened by disease (Harvell et al. 1999). In the Caribbean, a number of large-scale disease outbreaks over the last several decades have altered the structure 
of reef communities. However, studies documenting disease long-term dynamics on coral reefs have been rare. In their study, Kim \& Harvell (2004) employed data from 'snap-shot' surveys of the population (i.e. cross-sectional studies) to estimate impact of aspergillosis, a fungal disease, on the Caribbean sea fan coral Gorgonia ventalina. However, cross-sectional studies do not track individuals over time (in contrast to longitudinal studies) and therefore do not allow evaluation of key aspects of the natural history of disease, such as rates of disease progress and incidence rates. It is also unclear if a recovered sea fan is susceptible to subsequent infections and whether aspergillosis directly kills the host or whether it makes them susceptible to other causes of mortality. Answering these questions will provide insight on the interplay between pathogen and host, and aid in the prediction of the long-term impact of this disease (Anderson \& May 1991).

In spite of the value of longitudinal studies and the tractability of following sessile individuals over time, this technique has not been used with corals. In this study, we present a longitudinal analysis of aspergillosis in sea fan corals (see Nagelkerken et al. 1997a,b). The causative agent of aspergillosis is the soil fungus Aspergillus sydowii (Geiser et al. 1998), an apparent opportunistic pathogen. The main signs of aspergillosis are the presence of 2 types of pathological changes or lesions: (1) purpling of the tissue which is coincident with the absence of polyps in the area, and (2) tissue loss where the denuded axial skeleton is either exposed or has been fouled with algae and other organisms (Smith et al. 1996, Kim \& Harvell 2002). A longitudinal study consisting of photomonitoring and visual surveys of individually marked sea fans was used to follow the fates of individual infections in order to estimate incidence, recovery, and mortality.

\section{MATERIALS AND METHODS}

This work was carried out at several reefs in the Florida Keys which have been sites of long-term monitoring of sea fan aspergillosis (Kim \& Harvell 2004). To track the fate of sea fan aspergillosis, we established a photomonitoring program at Western Dry Rocks, a patch reef near Key West, Florida. In June 1996, all Gorgonia ventalina colonies ( $\mathrm{n}=20$ healthy, 20 diseased) in a small area of the reef $(\sim 20 \times 20 \mathrm{~m}$, depth $5 \mathrm{~m}$ ) were tagged by fastening numbered aluminum tags to nails driven into the substratum near the colony bases. Colonies were photographed in June 1996, August 1996, April 1997, July 1997, November 1997, and May 1998. Not all sea fans were photographed at every date. A scale bar, which was included in each picture (see Fig.1), was used to analyze the images using NIH Image (v. 1.62, U.S. National Institutes of Health). The images were used to determine colony size, disease severity ( $\%$ of sea fan area with diseased tissue), and incidence rates (number of disease onsets divided by the length of observation time for each fan; Rothman \& Greenland, 1998), and mortality rate (number of sea fans dying per year).

We also followed the fates of individual infections to understand disease progress. It should be noted that in the absence of data confirming the presence of Aspergillus sydowii in all affected tissue, it is possible that factors other than aspergillosis were responsible for the lesions. Previous observation suggested that disease signs can be categorized as: (1) small purpling $(<0.1 \%$ of the sea fan area), (2) larger purpling ( $>1 \%$ of sea fan area), (3) tissue loss with associated purpling, or (4) tissue loss without purpling. Given that purpling takes a week or more to develop (Alker et al. 2004), we hypothesize that tissue loss without purpling is indicative of active disease progression.

The dynamics of infections were investigated by calculating a transition probability matrix. For instance, we estimated how likely it was for a small purpling to turn into a large purpling and for infections to be lost (i.e. sea fan recovers) in a given year. For this analysis, transitions were calculated for each of 2 periods: 1996 to 1997 and 1997 to 1998 ; however, because there were not enough data for each of the 4 infection types for any given year, transition probabilities for each of the 2 yr were combined.

In addition, localized outbreaks (i.e. increase in disease prevalence and severity; see Kim \& Harvell 2004) of aspergillosis provided opportunities to document spatial and temporal variability in disease impact. In May 1998, an outbreak was noted at Conch, a reef located in the Upper Keys. To document this outbreak, 19 diseased and 5 healthy sea fans were tagged. For comparison, we tagged an additional 25 diseased, 5 healthy sea fans at Carysfort, a reef that is among the most healthy (i.e. high sea fan densities, low disease impact, high recruitment; see Kim \& Harvell 2004). Both sites were visually monitored again in September 1999 to estimate mortality. In July 2000, a second outbreak was noted, this time at Carysfort. A total of 28 initially healthy and 34 initially diseased sea fans were tagged and re-surveyed in May 2001.

\section{RESULTS}

Of the 40 sea fans examined at Western Dry Rocks, 20 displayed signs of aspergillosis (Fig. 1) and 19 appeared healthy. One fan had purplings associated with hydroids and was excluded from further analysis 

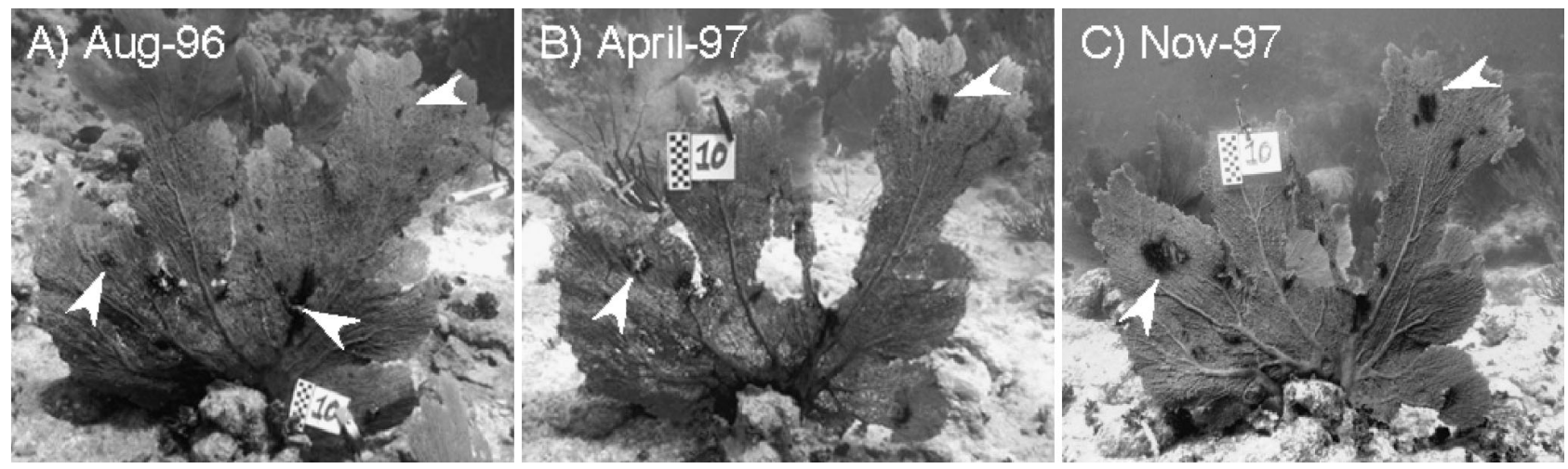

Fig. 1. Gorgonia ventalina. Time-series photographs of a sea fan at Western Dry Rock infected with aspergillosis. Note the progress of purpling infections into tissue loss with purpling (lower left arrowhead in (A) or larger purpling (upper right arrowhead in (A). Squares on the scale bar $=1 \mathrm{~cm}$

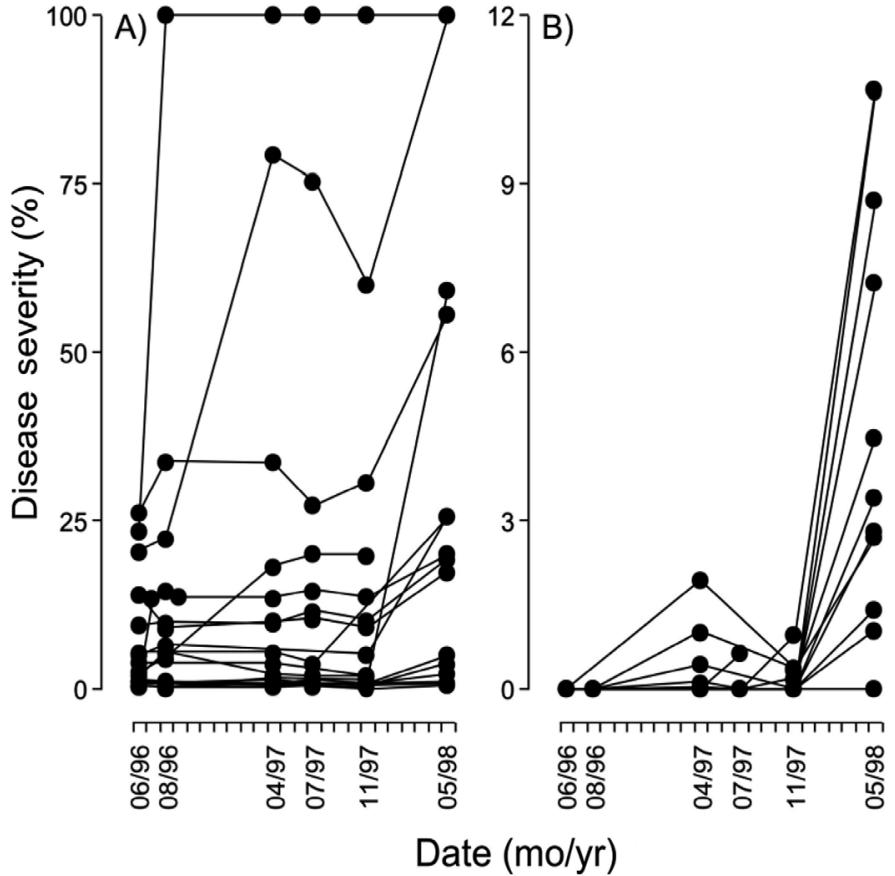

Fig. 2. Gorgonia ventalina. Fates of (A) infections on initially diseased sea fans $(n=19)$ and $(B)$ initially healthy sea fans (n $=19$ ). Each line represents a single sea fan connected to times when photo-monitoring surveys were carried out. Severity is given as the total percentage of colony surface area infected with aspergillosis, where $100 \%$ severity represents whole colony mortality. Note the differences in scales of vertical axes between (A) and (B)

(see Alker et al. 2004). One initially diseased fan had too many purplings to be traced over time and therefore only the fate of the fan and not of the individual infections was noted. There was a 2 yr case fatality rate of $10 \%$ (2 out of 20) among initially diseased sea fans or a mortality rate of $5 \%$ per year among diseased sea fans (Fig. 2A). In both cases of complete mortality, the 2 sea fans started out with similar disease severity $(\sim 25 \%)$; however, the rates of disease progress in the 2 sea fans were strikingly different. Whereas one died within 2 mo of first observation, the other died after a period of almost $2 \mathrm{yr}$.

In $80 \%$ of the cases, disease severity did not increase above $25 \%$ over the 2 yr of observation. Three sea fans recovered (with no visible disease signs), but only temporarily, with new infections appearing in areas not previously infected. Among initially healthy fans, incidence rate was 0.58 per sea fan $\mathrm{yr}^{-1}$. At this rate approximately 5.8 fans will become infected over a period of $10 \mathrm{yr}$. However, the probability of acquiring the disease varied with time, with most of the infections occurring between November 1997 and May 1998.

In terms of individual infections, the fates and dynamics of purplings and areas of tissue loss differ. Specifically, purpling is much more dynamic: incidence (rate of new infections entering the infected population) of both small and large tissue purpling was much higher than for areas of tissue loss (Fig. 3). Purplings can turn into areas of tissue loss, but at a very low rate of $1.2 \% \mathrm{yr}^{-1}$ (8 of 332 in $2 \mathrm{yr}$ ) and were more likely to disappear, with the sea fan recovering from them-in contrast to areas of tissue loss, which tended to remain unchanged.

During an aspergillosis outbreak at Conch in May 1998, mortality among diseased sea fans was $46 \%$ $\mathrm{yr}^{-1}$. In contrast, at Carysfort, a less impacted reef, mortality was $8 \% \mathrm{yr}^{-1}$ during the same period (Fig. 4). However, during an outbreak in July 2000, mortality at Carysfort was substantially higher at 95\% $\mathrm{yr}^{-1}$ ( 27 of 34 sea fans died during the monitoring period) with infection incidence of 0.35 sea fans $\mathrm{yr}^{-1}$ (8 of 28 initially healthy sea fans became infected). 


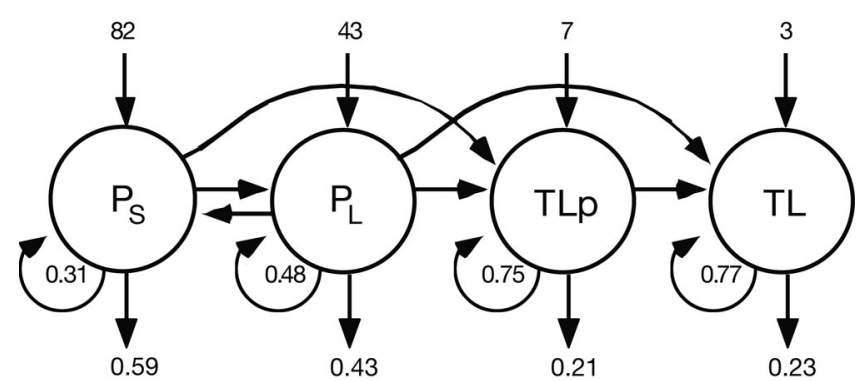

Fig. 3 Gorgonia ventalina. Dynamics of purplings and tissue loss. Circles represent the 4 infection types: $\mathrm{P}_{\mathrm{S}}=$ small purpling $(<0.1 \%$ of the colony surface area $), \mathrm{P}_{\mathrm{L}}=$ large purpling $(>0.1 \%$ of the fan surface area), TLp = tissue loss with associated tissue purpling, TL $=$ tissue loss without purpling. Top row of numbers (above arrows): number of new infections entering the population each year. Numbers in arrow loop and below arrows: transition probabilities for stasis, and recovery, respectively. Unlabeled transition indicate probability of $<0.01$

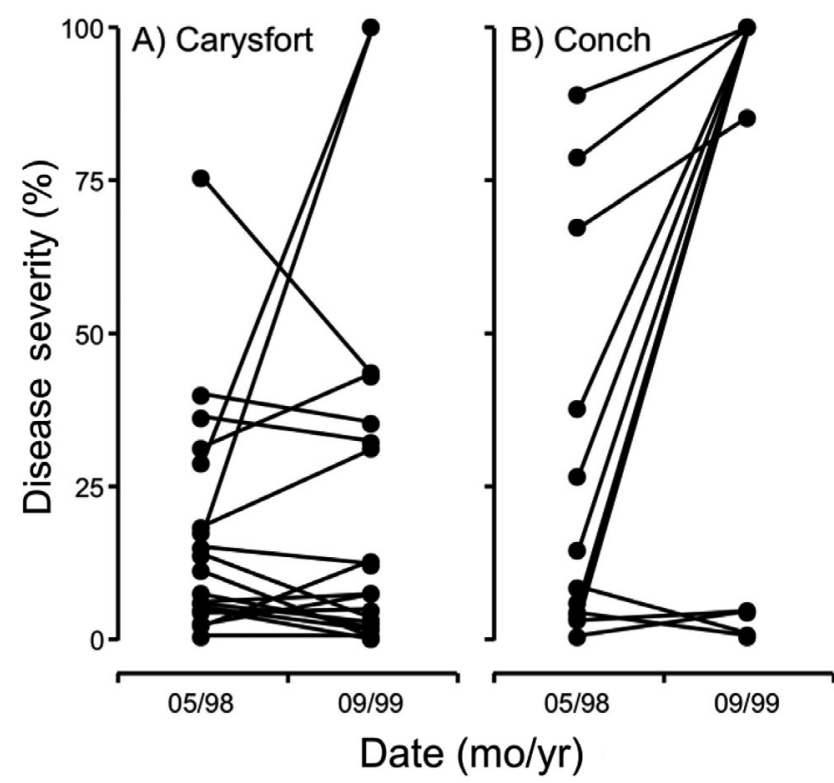

Fig. 4. Gorgonia ventalina. Fates of sea fans tagged in May 1998 during an outbreak at 2 reefs. Data were collected using visual censuses. Note that $100 \%$ severity represents complete mortality

\section{DISCUSSION}

The interaction between host and pathogen in the Aspergillus-Gorgonia system is dynamic due to a range of factors. For instance, previous studies have noted the importance of variation in pathogen virulence and transmission, host resistance (Kim \& Harvell 2004), and environmental conditions such as temperature (Alker et al. 2001, Harvell et al. 2002) and water quality (Bruno et al. 2003). Out of the 28 sea fans that were initially healthy, only $12(43 \%)$ remained free of disease signs at the end of $2 \mathrm{yr}$ of monitoring, suggesting that most sea fans are susceptible to aspergillosis. The probability of acquiring an infection appears to change over time, with the largest increase in incidence occurring during winter and spring months (Fig. 2B). This finding suggests that dynamics of aspergillosis may be set during the winter and spring months and subsequently exacerbated during the summer, when increasing temperature is thought to favor the pathogen over the host (Harvell et al. 2002, Kim \& Harvell 2004). The importance of winter temperature has been noted in the dynamics of Perkinsus marinus, a pathogen of oysters. In this pathosystem, warmer winters reduce pathogen mortality, resulting in oysters retaining heavy infections (Ford 1996). Given the limited duration of this current study, a test of this hypothesis is not possible.

Purpling can progress into areas of tissue loss, albeit at very low rates (Fig. 3). Most commonly, disease progresses very little (stasis) or becomes lost (i.e. the host recovers from that particular infection). Recovery from tissue purpling is more common than from tissue loss. Once tissue loss occurs, the exposed skeleton is rapidly fouled over, thereby effectively limiting recovery in that area of the sea fan. In contrast, purpling, which is only associated with the loss of polyps and not the coenenchyme (tissue between polyps), is presumably easier to recover from.

Previous studies indicate that the purpling is a host response induced by the presence of the fungus (Petes et al. 2003, Alker et al. 2004, Mullen et al. 2004). Given that tissue purpling only rarely progresses to tissue loss, we suggest that the underlying process that leads to purpling is an effective mechanism of disease resistance. Indeed, purpling may indicate a generalized response to a range of biotic interactions as evidenced by increased resistance of purpled areas to overgrowth by the competitively dominant fire coral Millepora alcicornis (Alker et al. 2004).

Tissue loss appears to be an important stage in disease progression. Although not all sea fans with areas of tissue loss suffered mortality, all colonies that died during the course of this study had areas of tissue loss (Figs. 2 to 4 ). However, the rate at which tissue loss progresses to whole colony mortality is highly variable. At Western Dry Rocks, the 2 sea fans that died during the course of this study showed similar levels of disease severity but differed greatly in disease progress ( 2 mo versus $2 \mathrm{yr}$ for mortality). Given that 2 sea fans occupied the same environment, the variation in disease progress is likely due to a range of biotic factors which may include host susceptibility (Kim et al. 2000). We also found that mortality can increase dramatically during localized outbreaks. Mortality was $46 \% \mathrm{yr}^{-1}$ at 
Conch and $95 \% \mathrm{yr}^{-1}$ at Carysfort during 2 separate events. As discussed in Kim \& Harvell (2004), possible explanations for such variation in disease impact are difficult to elucidate, given the complex interplay between the host, pathogen, and the environment and the lack of long-term base line data. We suggest that in addition to large-scale surveys, longitudinal studies will be needed to begin understanding key features of disease dynamics.

Acknowledgements. We are grateful to D. Dube for assistance in the field and N. Tische for advice on the data analysis. We thank the National Oceanic and Atmospheric Administration National Undersea Research Center (NOAA-NURC) program and staff in Key Largo and Reef Relief in Key West for support of our work. Comments from N. Hairston Jr., E. Kim, and the aquatic ecology group at American University are gratefully acknowledged. This research was supported by grants to C. D. Harvell and K. Kim (NSF OCE-9614004, NURC-UNCW 9821).

\section{LITERATURE CITED}

Alker AP, Smith GW, Kim K (2001) Characterization of Aspergillus sydowii (Thom et Church), a fungal pathogen of Caribbean sea fan corals. Hydrobiologia 460:105-111

Alker AP, Dube D, Harvell CD, Kim K (2004) Localized induction of a generalized response against multiple biotic agents in Caribbean sea fan corals. Coral Reefs 23: 397-405

Anderson RM, May RM (1991) Infectious diseases of humans. Oxford University Press, Oxford

Bruno JF, Petes LE, Drew Harvell C, Hettinger A (2003) Nutrient enrichment can increase the severity of coral diseases. Ecol Letters 6:1056-1061

Ford SE (1996) Range extension by the oyster parasite Perkinsus marinus into the northeastern United States: response to climate change? J Shellfish Res 15:45-56

Geiser DM, Taylor JW, Ritchie KB, Smith GW (1998) Cause of

Submitted: December 23, 2004; Accepted: May 6,2005 sea fan death in the West Indies. Nature 394:137-138

Harvell C, Kim K, Burkholder J, Colwell R and 9 others (1999) Emerging marine diseases-climate links and anthropogenic factors. Science 285:1505-1510

Harvell CD, Mitchell CE, Ward JR, Altizer S, Dobson A, Ostfeld RS, Samuel MD (2002) Climate warming and disease risks for terrestrial and marine biota. Science 296: $2158-2162$

Kim K, Harvell CD (2002) Aspergillosis of sea fan corals: disease dynamics in the Florida Keys. In: Porter JW, Porter KG (eds) The Everglades, Florida Bay and coral reefs of the Florida Keys: an Ecosystem sourcebook. CRC Press, Washington, DC, p 813-823

Kim K, Harvell CD (2004)The rise and fall of a six-year coralfungal epizootic. Am Nat 164:S52-S63

Kim K, Harvell CD, Kim PD, Smith GW, Merkel SM (2000) Fungal disease resistance of Caribbean sea fan corals (Gorgonia spp.). Mar Biol 136:259-267

McCallum HI, Kuris A, Harvell CD, Lafferty KD, Smith GW, Porter JW (2004) Does terrestrial epidemiology apply to marine systems? Trends Ecol Evol 19:585-591

Mullen K, Harvell CD, Peters E (2004). Coral resistance to disease. In: Rosenberg E, Loya Y (eds) Coral health and disease. Springer-Verlag, New York

Nagelkerken I, Buchan K, Smith GW, Bonair K and 10 others (1997a) Widespread disease in Caribbean sea fans. II. Patterns of infection and tissue loss. Mar Ecol Prog Ser 160: 255-263

Nagelkerken I, Buchan K, Smith GW, Bonair K and 8 others (1997b) Widespread disease in Caribbean sea fans. I. Spreading and general characteristics. Proc 8th Int Coral Reef Symp 1:679-682

Petes L, Harvell CD, Peters EC, Webb MAH, Mullen KM (2003) Pathogens compromise reproduction and induce melanization in Caribbean sea fans. Mar Ecol Prog Ser 264:167-171

Rothman KJ, Greenland S (1998) Modern epidemiology, 2nd edn. Lippincott Williams \& Wilkins, Philadelphia, PA

Smith G, Ives L, Nagelkerken I, Ritchie K (1996) Caribbean sea-fan mortalities. Nature 383:487

Ward JW, Lafferty KD (2004) The elusive baseline of marine disease: Are diseases in ocean ecosystems increasing? PLoS Biol 2:0542-0547

Proofs received from author(s): December 22, 2005 